\title{
Pemanfaatan Sari Pati Umbi Gadung (Dioscorea hispida Dennst) Untuk Koagulasi Lateks Karet Alam (Hevea brasiliensis)
}

\author{
FITRIA LESTARI ${ }^{1}$, YULI FEBRIANTI ${ }^{1}$, JOKO WIYONO ${ }^{1}$ \\ ${ }^{1}$ Program Studi Pendidikan Biologi STKIP PGRI Lubuklinggau \\ Jl. Mayor Toha Kelurahan Air Kuti, Lubuklinggau Timur I, Lubuklinggau, \\ Sumatera Selatan. 31626 \\ Email: fitrinq@gmail.com
}

Received 24 January 2018; Received in revised form 8 February 2018;

Accepted 14 February 2018; Available online 11 April 2018

\begin{abstract}
This research aims to know the utilization of gadung (Dioscorea hispida Dennst) tuber concentrate on natural latex (Hevea brasiliensis) rubber coagulation. The design used in this study was completely randomized design (RAL) with 6 treatments and 4 replications consisting of control and treatment group with concentration of $20 \mathrm{ml}, 40 \mathrm{ml}, 60 \mathrm{ml}, 80 \mathrm{ml}$ and $100 \mathrm{ml}$. The parameters observed were latex coagulation by administering some concentrations of gadung tuber. One way Anava test with $0.05 \%$ significance level showed significant result that is $\mathrm{F}_{\text {count }}=53$ and $\mathrm{F}_{\text {table }}=2,77$. This shows that gadung tuber concentrate gives a very real effect on latex coagulation. Thus it can be concluded that there is the effect of gadung tuber concentrate to natural rubber latex coagulation.
\end{abstract}

Keywords: coagulation, gadung tuber concentrate, natural latex

\section{INTISARI}

Telah dilakukan penelitian pemanfaatan sari pati umbi gadung (Dioscorea hispida Dennst) terhadap koagulasi lateks karet alam (Hevea brasiliensis) yang bertujuan untuk mengetahui pengaruh beberapa konsentrasi sari pati umbi gadung terhadap koagulasi lateks karet alam. Rancangan yang digunakan dalam penelitian ini adalah rancangan acak lengkap (RAL) dengan 6 perlakuan dan 4 kali pengulangan yang terdiri dari kelompok kontrol dan kelompok perlakuan dengan konsentrasi $20 \mathrm{ml}$, $40 \mathrm{ml}, 60 \mathrm{ml}, 80 \mathrm{ml}$ dan $100 \mathrm{ml}$. Parameter yang diamati adalah koagulasi lateks dengan pemberian beberapa konsentrasi sari pati umbi gadung. Uji anava satu jalur dengan taraf signifikasi $0,05 \%$ menunjukkan hasil yang signifikan yaitu $F_{\text {hitung }}=53$ dan $F_{\text {tabel }}=2,77$. Hal ini menunjukkan sari pati umbi gadung memberikan pengaruh yang sangat nyata terhadap koagulasi lateks. Demikian dapat disimpulkan bahwa ada pengaruh sari pati umbi gadung terhadap koagulasi lateks karet alam.

Kata kunci: karet alam, koagulasi, lateks alam, sari pati umbi gadung

\section{PENDAHULUAN}

Tanaman karet mulai dikenal Indonesia sejak zaman penjajahan Belanda. Di Indonesia, karet alam (Hevea brasiliensis) banyak dimanfaatkan secara luas dalam skala industri maupun untuk kepentingan masyarakat (Sari dan Rahayu, 2013). Karet menjadi komoditas penting selain kelapa sawit, teh dan kakao, baik sebagai pendapatan devisa, kesempatan kerja dan pendorong pertumbuhan ekonomi sentra-sentra baru di wilayah sekitar perkebunan karet maupun pelestarian lingkungan serta sumber daya hayati. Hal ini ditunjukkan oleh jumlah petani yang terlibat dalam usaha karet alam mencapai 1,907 juta kepala keluarga sehingga banyak penduduk menggantungkan hidup dari tanaman ini (Sannia $d k k$., 2013).

Koagulasi lateks yang biasa dilakukan petani di Sumatera Selatan pada umumnya dengan menambahkan bahan tambahan seperti cuka (asam sulfat) dan asam formiat ke dalam lateks sebagai koagulasi lateks. Namun, hasil jual karet yang sekarang sangat turun tidak 
sebanding dengan harga cuka sintetis. Harga cuka sintetis Rp. 11.000 per botol sedangkan harga karet Rp. 4.000 per kilo (Gapkindo, 2017). Oleh karena itu, salah satu alternatif untuk mengurangi biaya produksi dan ramah lingkungan, yaitu menggunakan umbi gadung sebagai cara untuk koagulasi lateks. Menurut Purbaya $d k k$. (2011) selain asam asetat dan asam formiat terdapat asam lain yang dapat menggumpalkan lateks yang membuat protein terhidrolisa menjadi asam amino.

Koagulasi menggunakan sari pati umbi gadung merupakan koagulasi berbahan dasar alami yang aman bagi petani walaupun memiliki kandungan sianida ( $\mathrm{HCN})$ yang bersifat toksik (Lokman et al., 2017), namun dengan mencuci tangan setelah bersentuhan langsung atau setelah selesai menggunakan umbi gadung maka hal tersebut tidak akan berbahaya, sehingga lebih ramah lingkungan dan dapat diproduksi sendiri oleh petani secara konvensional. Pemanfaatan umbi gadung dalam penelitian ini dikarenakan keberadaannya yang banyak, tersebar dan mudah ditemukan serta secara ekonomis lebih menguntungkan sehingga dapat menurunkan biaya produksi.

Berdasarkan uraian tersebut maka dilakukan penelitian untuk mengetahui pengaruh beberapa konsentrasi sari pati umbi gadung terhadap koagulasi lateks karet alam.

\section{METODE}

Umbi gadung (Dioscorea hispida Dennst) dan lateks segar (Hevea brasiliensis) yang digunakan sebagai bahan penelitian diambil dari perkebunan di Desa Petunang, Tuah Negeri, Kabupaten Musi Rawas.

Pembuatan Sari Pati Koagulasi Umbi Gadung. Umbi gadung sebanyak $1 \mathrm{~kg}$ dibersihkan dari kotoran yang menempel dan dikupas kulitnya, kemudian dicuci dengan air yang bersih. Umbi Gadung dipotong menjadi empat bagian dan diparut dengan menggunakan parut kaleng. Umbi gadung diperas dan ditampung dalam nampan plastik yang sudah disediakan. Sari pati umbi gadung siap digunakan sebagai koagulasi/penggumpal lateks karet alam.

Persiapan Lateks Murni. Sebanyak 600 $\mathrm{ml}$ lateks dibagi menjadi masing-masing 100 $\mathrm{ml}$ lateks segar dan dimasukkan ke dalam gelas kimia dengan diberi label $\mathrm{K}$ (Kontrol), L1 (Lateks 1), L2 (Lateks 2), L3 (Lateks 3), L4 (Lateks 4), L5 (Lateks 5).

Perlakuan Sari Pati Umbi Gadung Sebagai Koagulasi Lateks Karet Alam. Lateks kebun disediakan sebanyak $600 \mathrm{ml}$. Masing-masing $100 \mathrm{ml}$ lateks segar dimasukkan ke dalam gelas kimia, gelas kimia 1 yang diberi label $\mathrm{K}$ sebagai kontrol dengan memberikan $20 \mathrm{ml}$ cuka sintetis sebagai kontrol positif. Lateks pada gelas kimia 2 sampai gelas kimia 6 ditambahkan konsentrasi sari pati umbi gadung dengan volume penambahan $20 \mathrm{ml}, 40 \mathrm{ml}, 60 \mathrm{ml}, 80 \mathrm{ml}$, dan $100 \mathrm{ml}$. Selanjutnya didiamkan dan dilakukan pencatatan lama waktu yang dibutuhkan sari pati umbi gadung dalam koagulasi lateks (Gambar 1).

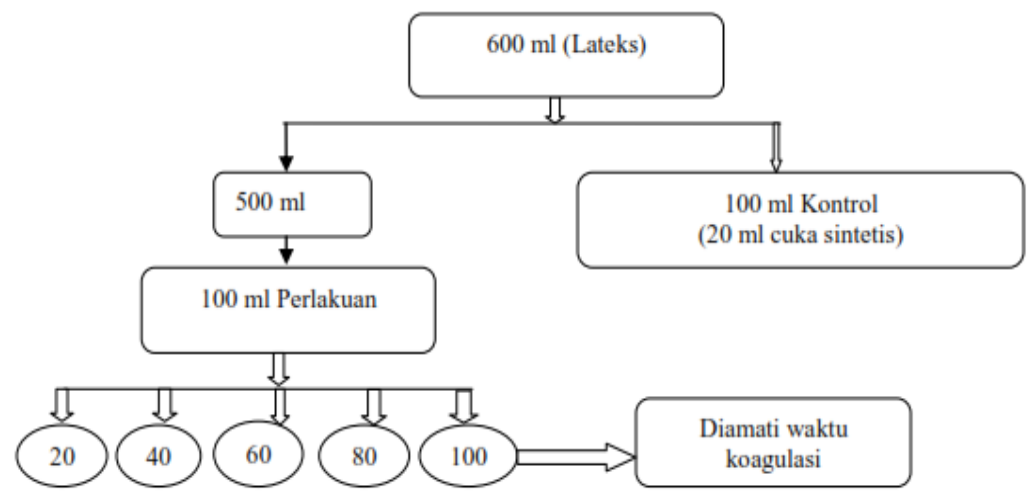

Gambar 1. Penggunaan sari pati umbi gadung (Safitri, 2009) 
Rancangan Percobaan. Penelitian ini menggunakan rancangan acak lengkap (RAL) dengan 6 perlakuan dan 4 pengulangan. Perlakuan terdiri dari $\mathrm{P} 0=20 \mathrm{ml}$ menggunakan cuka sintetis, $P 1=20 \mathrm{ml}$ sari pati umbi gadung,
$\mathrm{P} 2=40 \mathrm{ml}$ sari pati umbi gadung, $\mathrm{P} 3=60 \mathrm{ml}$ sari pati umbi gadung, $\mathrm{P} 4=80 \mathrm{ml}$ sari pati umbi gadung, $\mathrm{P} 5=100 \mathrm{ml}$ sari pati umbi gadung. Penelitian ini terdapat enam kelompok dan empat kali pengulangan (Tabel 1).

Tabel 1. Pemberian perlakuan sari pati umbi gadung (Safitri, 2009)

\begin{tabular}{cccc}
\hline No. & Kelompok perlakuan & Ulangan & Konsentrasi sari pati umbi gadung \\
\hline $\mathbf{1}$ & P0 & 4 & $20 \mathrm{ml}$ (cuka sintetis) \\
\hline $\mathbf{2}$ & P1 & 4 & $20 \mathrm{ml}$ \\
\hline $\mathbf{3}$ & P2 & 4 & $40 \mathrm{ml}$ \\
\hline $\mathbf{4}$ & P3 & 4 & $60 \mathrm{ml}$ \\
\hline $\mathbf{5}$ & P4 & 4 & $80 \mathrm{ml}$ \\
\hline $\mathbf{6}$ & P5 & 4 & $100 \mathrm{ml}$ \\
\hline
\end{tabular}

HASIL

Hasil pengukuran rata-rata koagulasi (Tabel 2) menunjukkan bahwa perlakuan dengan menggunakan cuka sintetis (P0) lebih cepat mengalami koagulasi yaitu 1,04 menit.

Tabel 2. Rata-Rata hasil perlakuan koagulasi lateks karet alam (Hevea brasiliensis)

\begin{tabular}{ccc}
\hline Perlakuan (Konsentrasi) & Ulangan & Rata-Rata (Menit) koagulasi lateks \\
\hline P0 20 ml cuka sintetis & 4 & $1,04 \mathrm{a}$ \\
\hline P1 20 ml sari pati umbi gadung & 4 & $2,13 \mathrm{c}$ \\
\hline P2 40 ml sari pati umbi gadung & 4 & $1,46 \mathrm{~b}$ \\
\hline P3 60 ml sari pati umbi gadung & 4 & $1,55 \mathrm{~b}$ \\
\hline P4 80 ml sari pati umbi gadung & 4 & $1,47 \mathrm{~b}$ \\
\hline P5 100 ml sari pati umbi gadung & 4 & $1,27 \mathrm{a}$ \\
\hline
\end{tabular}

Setelah pengukuran rata-rata waktu koagulasi, langkah selanjutnya adalah menganalisis data menggunakan Anava
(Analisis Varian) (Tabel 3). Hasil perhitungan dengan menggunakan Anava diperoleh bahwa $F_{\text {hitung }}=53>$ dibandingkan dengan $F_{\text {hitung }} 4,25$.

Tabel 3. Hasil perhitungan analisis varian koagulasi lateks

\begin{tabular}{cccc} 
Sumber Varian & Fitung $_{\text {Antar Kelompok }}$ & $\mathbf{F}_{\text {tabel }}$ & Interpretasi \\
\hline \begin{tabular}{c} 
Perlakuan \\
\hline
\end{tabular} & 53 & 4,25 & Signifikan \\
\hline
\end{tabular}

\section{PEMBAHASAN}

Hasil perhitungan menunjukkan bahwa $\mathrm{F}_{\text {hitung }}=53>$ dibandingkan dengan $\mathrm{F}_{\text {hitung }}=$ 4,25. Hal ini berarti bahwa penggunaan sari pati umbi gadung berpengaruh nyata terhadap koagulasi lateks karet alam. Koagulasi merupakan proses untuk mempersatukan butirbutir karet yang terdapat dalam cairan lateks, sehingga membentuk satu koagulum atau gumpalan dan proses koagulasi. Hal ini terjadi akibat adanya penurunan $\mathrm{pH}$ (Purnomo $d k k$., 2014).
Untuk mengetahui perlakuan yang berpengaruh nyata diantara 6 perlakuan yang ada, selanjutnya dilakukan uji lanjut menggunakan uji BNT. Perhitungan menggunakan uji lanjut menunjukkan bahwa semakin besar konsentrasi sari pati umbi gadung yang diberikan, maka proses koagulasi lateks akan semakin cepat yang ditunjukkan pada perlakuan dengan konsentrasi $100 \mathrm{ml}$ (P6).

Terjadinya koagulasi pada lateks karet alam dengan menggunakan sari pati umbi 
gadung diakibatkan oleh adanya muatan negatif pada emulgator lateks yang bereaksi dengan asam sehingga mengakibatkan terjadinya proses netralisasi dimana emulgator kehilangan muatan (Gambar 2). Penyebab adanya muatan negatif adalah penguraian lateks sehingga lapisan pelindung partikel karet akan rusak yang menyebabkan terjadi penurunan $\mathrm{pH}$ dan interaksi antara partikel karet (Ali $d k k .$, 2010).

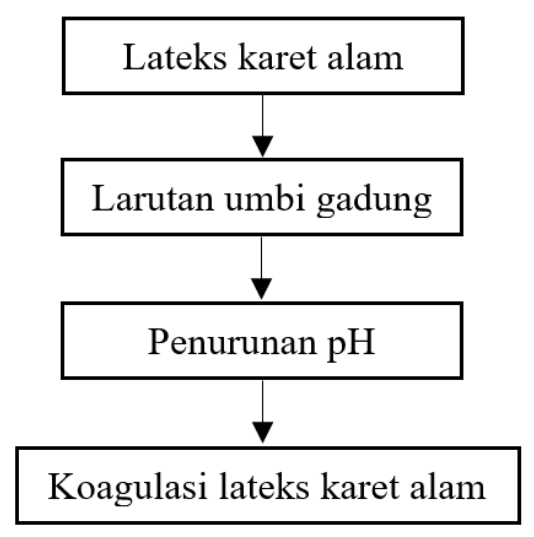

Gambar 2. Proses koagulasi lateks karet alam (Hevea brasiliensis)

Selain koagulasi, warna lateks yang menggunakan sari pati umbi gadung akan berwarna putih keunguan jika dibandingkan dengan cuka sintetis. Hal ini dikarenakan warna yang sempurna untuk koagulasi karet yaitu memiliki kriteria warna putih kekuningan (Purnomo dkk., 2014).

\section{KESIMPULAN}

Berdasarkan hasil analisis data pengamatan disimpulkan bahwa sari pati umbi gadung (Dioscorea hispida Dennst) dapat dimanfaatkan untuk koagulasi lateks karet alam (Hevea brasiliensis) yang diuji menggunakan Anava satu jalur. Dengan $F_{h i t u n g}$ $=53$ dan $\mathrm{F}_{\text {tabel }}=2,77$ maka Ha diterima dan $\mathrm{HO}$ ditolak, sehingga dapat disimpulkan bahwa umbi gadung berpengaruh terhadap koagulasi lateks karet alam dengan konsentrasi yang berpengaruh adalah pada perlakuan (P3) 60 $\mathrm{ml}$.

\section{UCAPAN TERIMAKASIH}

Penulis mengucapkan terima kasih kepada Pemerintah Kabupaten Musi Rawas khususnya Kecamatan Tuah Negeri Desa Petunang yang telah memberikan izin untuk melakukan penelitian dan lembaga STKIP
PGRI Lubuklinggau yang memberikan dukungan untuk terlaksananya penelitian ini.

\section{DAFTAR PUSTAKA}

Ali F, Sihombing A, Fauzi A. 2010. Koagulasi Lateks dengan (Dioscorea hispida Dennts). Jurnal Teknik Kimia. vol 17(3): 8-16.

Gapkindo. 2017. Harga Jual Karet di Batanghari Rendah. Jakarta: Gabungan Pengusaha Karet Indonesia. https://www.gapkindo.org/. diakses Oktober 2017.

Lokman EF, Muhammad H, Awang N, Omar MH, Mansor F, Saparuddin F. 2017. Gene Expression Profiling associated with Hepatoxicity in Pregnant Rats treated with Ubi Gadong (Dioscorea hispida) Extract. Int J Biomed Sci. vol 13(1): 26-34.

Purbaya M, Sari TI, Saputri CA, Fajriaty MT. 2011. Pengaruh Beberapa Jenis Bahan Penggumpal Lateks dan Hubungannya dengan Susut Bobot, Kadar Karet Kering dan Plastisitas. Prosiding Seminar Nasional AVoER ke-3. 26-27 Oktober 2011. Palembang: Fakultas Teknik Universitas Sriwijaya. ISBN: 979-587395-4. hal 351-357. 
Purnomo LJ, Nurhayati, Fatimah. 2014. Pemanfaatan Buah Limpasu (Baccaurea lanceolata) Sebagai Pengental lateks Alami. Jurnal Teknologi Agro-Industri. vol 1(1): 24-32.

Safitri K. 2009. Pengaruh Ekstrak Belimbing Wuluh (Averrhoa bilimbi L.) Sebagai Penggumpal Lateks terhadap Mutu Karet. [Skripsi]. Medan: Program Studi Dapartemen Kimia Fakultas Matematika dan Ilmu Pengetahuan Alam Universitas Sumatera Utara.
Sannia B, Ismono RH, Viantimala B. 2013. Hubungan Kualitas Karet Rakyat dengan Tambahan Pendapatan Petani didesa Program dan non Program. Jurnal IlmuIlmu Agribisnis. vol 1(1): 36-43.

Sari HFM dan Rahayu SSB. 2013. Jenis-Jenis Gulma yang ditemukan di Perkebunan Karet (Hevea brasiliensis Roxb.) Desa Rimbo Datar Kabupaten 50 Kota Sumatera Barat. Biogenesis. vol 1(1): 2832. doi: https://doi.org/10.24252/bio.v1i1.444. 